\title{
HETEROLOGOUS ANTIGEN EXTRACT IN ELISA FOR THE DETECTION OF HUMAN IgE ANTI-Strongyloides stercoralis
}

\author{
Julia Maria COSTA-CRUZ(1), Joaquina MADAlENA(1), Deise Aparecida de Oliveira SILVA(1), Mônica Camargo SOPELETE(1), Dulcinéa Maria Barbosa CAMPOS(2)
}

\& Ernesto Akio TAKETOMI(1)

\begin{abstract}
SUMMARY
Strongyloides ratti larval extract was used for the standardization of ELISA to detect genus-specific IgE in human strongyloidiasis. Forty serum samples from monoinfected patients shedding S. stercoralis larvae (Group I), 40 from patients with other intestinal parasites (Group II), and 40 from copronegative healthy subjects (Group III) were analyzed. Genus-specific IgE levels (ELISA Index: EI) were significantly higher in the group I $(\mathrm{EI}=1.43)$ than groups II $(\mathrm{EI}=0.70)$ and $\mathrm{III}(\mathrm{EI}=0.71)$, showing positivity rates of $55 \%$, $2.5 \%$ and $0 \%$, respectively. Similarly, sera from copropositive patients had significantly higher levels of total $\mathrm{IgE}(866 \mathrm{IU} / \mathrm{mL})$ as compared to those from group II $(302 \mathrm{IU} / \mathrm{mL})$ and III $(143 \mathrm{IU} / \mathrm{mL})$. A significant positive correlation was found between levels of Strongyloides specific-IgE and total IgE in sera from patients with strongyloidiasis. In conclusion, S. ratti heterologous extract showed to be a useful tool for detecting genus-specific IgE by ELISA, contributing for a better characterization of the immune response profile in human strongyloidiasis.
\end{abstract}

KEYWORDS: Strongyloides stercoralis; Strongyloides ratti; Strongyloidiasis; IgE; ELISA.

\section{INTRODUCTION}

Strongyloides stercoralis causes chronic or subclinical intestinal infections in immunocompetent human hosts due to the occurrence of autoinfective larvae, which contribute to the maintenance of the population of adult worms in the intestine. S. stercoralis has unique feature of moulting from parasitic form to infective stage within the body rather than coming out and forming for indefinite period in an immunocompetent host. In addition, fatal hyperinfection or disseminated infection may occur in immunocompromised subjects like patients with cancer, organ transplant recipients, acquired immunodeficiency syndrome (AIDS), and patients upon corticoids and other immunosuppressive therapy, in whom it can involve any organ of the body ${ }^{1,10,29}$.

Strongyloidiasis is one of the most difficult parasitic infections to diagnose. Parasitological methods have poor sensitivity due to low parasite load or fluctuations of larval excretion in the majority of the infected individuals and they are time-consuming procedures ${ }^{9,31}$. In contrast, serological tests are more sensitive but the detection of specific IgG by enzyme-linked immunosorbent assay (ELISA) has shown crossreactivity with other helminth parasites ${ }^{6,12}$.

Although the IgE isotype is mainly associated with allergic responses and classified as type I hipersensitivity ${ }^{16}$, its relationship with helminth, protozoan and viral infections has been reported ${ }^{15,21,30}$. In human strongyloidiasis specific serum $\operatorname{IgE}$ levels using $S$. stercoralis antigen have been detected by radioimmunoallergosorbent test (RAST) ${ }^{13,20}$, ELISA $^{2,4,23}$ and immunoblotting assay ${ }^{4}$.

The major limitation found in the development of immunological tests for the diagnosis of strongyloidiasis is the low S. stercoralis larvae burden and consequently its low antigen recovery levels ${ }^{8}$. As Strongyloides ratti is readily maintained in laboratory rats it may represent a practical source of antigen. Immunological tests using S. stercoralis and $S$. ratti third-stage filariform larvae have shown comparable results ${ }^{7,14,27}$

Since in previous reports $S$. ratti antigens have not been employed for the detection of specific IgE, in this study we applied an IgE-ELISA using such heterologous antigen in human strongyloidiasis.

\section{MATERIAL AND METHODS}

Patients and serum samples: Serum samples were obtained from patients attended at the Hospital de Clínicas da Universidade Federal de Uberlândia, Minas Gerais, Brazil and divided into three groups based on the parasitological results according to the FERRIOLI ${ }^{11}$ and LUTZ ${ }^{19}$ methods. Serum samples of 120 individuals were analyzed, from which 40 were from monoinfected patients shedding S. stercoralis larvae in their feces (Group I; copropositive and seropositive for IgG anti-S. ratti; 23 


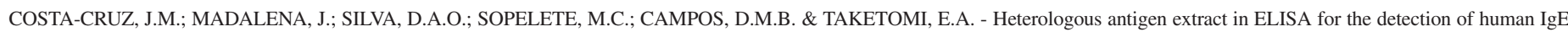
anti-Strongyloides stercoralis. Rev. Inst. Med. trop. S. Paulo, 45(5):265-268, 2003.

male, 17 female; age $=36.4 \pm 15.5$ years $)$. Group II consisted of 40 serum samples from monoinfected patients ( 14 male, 26 female; age $=18.7 \pm$ 13.6 years) with other intestinal parasites, such as hookworm (9 cases), Enterobius vermicularis (8 cases), Hymenolepis nana (6 cases), Trichuris trichiura (6 cases), Ascaris lumbricoides (5 cases), and Giardia lamblia (6 cases). Group III included 40 serum samples from healthy subjects who had repeatedly negative stool exams (copronegative; 23 male, 17 female; age $=27.0 \pm 13.1$ years). All subjects of groups II and III were seronegative for $\mathrm{IgG}$ anti-S. ratti. The protocol was approved by the Research Ethics Committee of the Universidade Federal de Uberlândia (CEP 28/2000), according to the federal Brazilian regulations ${ }^{22}$.

Parasites: S. ratti larvae were obtained from the feces of experimentally infected rats (Rattus rattus). The larvae were mixed with an equal part of finely ground charcoal, moistened with water, spread in a uniform layer on Petri dishes and incubated at $25{ }^{\circ} \mathrm{C}$ for 5 days. The filariform larvae were then harvested according to the FERRIOLI ${ }^{11}$ technique, concentrated by centrifugation at $1,000 \times \mathrm{g}$ for $5 \mathrm{~min}$ and stored at $-20{ }^{\circ} \mathrm{C}$ for using in the heterologous antigen preparation.

Heterologous antigen extract: $S$. ratti filariform larvae $(90,000)$ were suspended in $3 \mathrm{~mL}$ of $0.01 \mathrm{M}$ phosphate-buffered saline (PBS), $\mathrm{pH} \mathrm{7.2,} \mathrm{and} \mathrm{then} \mathrm{submitted} \mathrm{to} \mathrm{four} \mathrm{sonication} \mathrm{cycles} \mathrm{for} 5 \mathrm{~min}$ on ice bath at $40 \mathrm{kHz}$ (Thorton, Inpec Eletrônica São Paulo, SP, Brazil). After incubation overnight at $4{ }^{\circ} \mathrm{C}$ under continuous agitation, the antigen extract was centrifuged at $3,000 \times \mathrm{g}$ at $4{ }^{\circ} \mathrm{C}$ for $30 \mathrm{~min}$. Next, the protein concentration of the supernatant was determined according to LOWRY et al. ${ }^{18}$ and stored at $-20{ }^{\circ} \mathrm{C}$ for using as saline extract in ELISA.

Genus-specific serum IgE by ELISA: Specific IgE antibodies to Strongyloides sp. were measured in serum samples from groups I, II and III by indirect ELISA using a heterologous antigen extract, according to the described protocol by SILVA et al. ${ }^{28}$ with modifications. Briefly, microtiter plates were coated with $10 \mu \mathrm{g} / \mathrm{mL}$ of $S$. ratti saline extract in $0.06 \mathrm{M}$ carbonate buffer, $\mathrm{pH} 9.6$, overnight at $4{ }^{\circ} \mathrm{C}$. Plates were washed in PBS containing $0.05 \%$ Tween 20 (PBS-T) and blocked with PBS-T plus $1 \%$ bovine serum albumin (PBS-T-BSA) for one hour at room temperature (RT). Subsequent steps were carried out using PBS-T-BSA as diluent, and washings in PBS-T were done between the steps of the reaction. The plates were incubated with serum samples diluted at 1:2 in duplicate for $2 \mathrm{~h}$ at RT. Subsequently, biotinylated goat anti-human IgE (Kirkegaard \& Perry Laboratories Inc, Baltimore, MD, USA) was added (1:1000) and incubated for $1 \mathrm{~h}$ at RT, and further streptavidin-peroxidase conjugate (Sigma Chemical Co., St. Louis, MD, USA) diluted at 1:1000 was incubated for $30 \mathrm{~min}$ at RT. The assay was developed by adding the enzyme substrate $\left(0.01 \mathrm{M} \mathrm{ABTS}\right.$ and $\left.0.03 \% \mathrm{H}_{2} \mathrm{O}_{2}\right)$, and the absorbance (Abs) was read at $405 \mathrm{~nm}$ in a plate reader (Titertek Multiskan Plus, Flow Laboratories, USA). Positive and negative control sera were included in each assay. Positive serum was obtained from a patient who was shedding $S$. stercoralis larvae in the feces, and negative sera were obtained from four healthy subjects. The results were arbitrarily expressed as ELISA Index (EI) and calculated as follows: EI = Abs of serum sample / cut off, where cut off was determined as the mean absorbance of the negative control sera plus 5 standard deviations. Values of EI $>1.0$ were considered as positive.

Total serum IgE: A monoclonal antibody-based ELISA, modified from a previously described radioimmunoassay (RIA) by POLLART et $a l{ }^{24}$, was used for measuring total IgE antibodies. Briefly, microtiter plates were coated with mouse monoclonal anti-human IgE (Sigma Chemical Co.) at 1:5,000 in $0.06 \mathrm{M}$ carbonate buffer $\mathrm{pH} 9.6$ overnight at $4{ }^{\circ} \mathrm{C}$. Plates were washed and blocked as previously described. Serum samples diluted at 1:5, 1:25 and 1:125 were incubated for one hour at RT. Biotinylated goat anti-human IgE (Kirkegaard \& Perry Laboratories Inc.) diluted at 1:4,000 was added and incubated for one hour at RT. Subsequent steps (streptavidin-peroxidase and enzyme substrate) were carried out as described for specific IgE-ELISA. Total IgE results were expressed as international units per milliliter of serum and calculated based on a control curve obtained by serial two-fold dilutions of a serum (subject ARN) that was designated as containing 3,000 IU/mL of total $\mathrm{IgE}$. As reported by ROSE et al. (1996) $)^{26}, 1 \mathrm{IU} / \mathrm{mL}$ represents about $2.4 \mathrm{ng} / \mathrm{mL}$ of $\mathrm{IgE}$.

Statistical analysis: Determinations of geometric means (gm) with 95\% confidence intervals (CI) were calculated and the differences between the means were analyzed by the unpaired Student $t$ test. The group comparisons were performed using the differences between two proportions by Z statistic. Levels of total and Strongyloides-specific serum $\mathrm{IgE}$ were analyzed by Spearman correlation test. Values of $p<0.05$ were regarded as statistically significant.

\section{RESULTS}

As demonstrated in Figure 1, levels of Strongyloides-specific IgE (expressed in EI) were significantly higher $(p<0.0001)$ in copropositive patients (group I) (gm:1.43; 95\% CI: 1.17 - 1.75) than those obtained in patients with other parasites (group II) (gm: 0.70; 95\% CI: 0.67 - 0.73) and copronegative subjects (group III) (gm: 0.71; 95\% CI: $0.69-0.74$ ). Similarly, samples obtained from copropositive patients had significantly higher levels of total IgE (gm: $866 \mathrm{IU} / \mathrm{mL} ; 95 \% \mathrm{CI}: 438$ - 1,706) than those from the group II (gm: $302 \mathrm{IU} / \mathrm{mL} ; 95 \%$ CI: 163 - 558) and group III (gm: 143 IU/mL; 95\% CI: 48 - 424). However, no significant difference was found in the levels of both specific and total IgE between the two last groups $(p>0.05)$. Thus, the positivity rate for IgE anti-Strongyloides was $55 \%$ in the copropositive group compared with $2.5 \%$ in the group with other parasites and $0 \%$ in the copronegative group $(p<0.001)$.

Figure 2 shows a significant positive correlation (Spearman $\mathrm{r}=$ 0.6326; $p<0.0001$ ) between levels of Strongyloides-specific IgE and total IgE in sera from patients with strongyloidiasis (Group I). Furthermore, 21/22 (95.4\%) patients with IgE anti-Strongyloides had a total IgE value greater than $100 \mathrm{IU} / \mathrm{mL}$ and 20/22 (90.9\%) showed values greater than $1000 \mathrm{IU} / \mathrm{mL}$ of total $\mathrm{IgE}$.

\section{DISCUSSION}

Human strongyloidiasis is usually an asymptomatic or chronic infection in immunocompetent hosts, but it can be a severe parasitosis with potentially fatal auto-infection in immunocompromised subjects. The majority of the cases are underdiagnosed due to the lack of defined symptoms, thus contributing for the infection dissemination, particularly in tropical and subtropical countries ${ }^{9}$. The difficult mass production of S. stercoralis larvae, with the involved risk of infectivity for laboratory technicians, can be avoided because of the feasibility of safe and easy mass production of $S$. ratti larvae, an adequate substitute antigen, as proven in our previous studies using indirect immunofluorescence reaction ${ }^{7}$. 


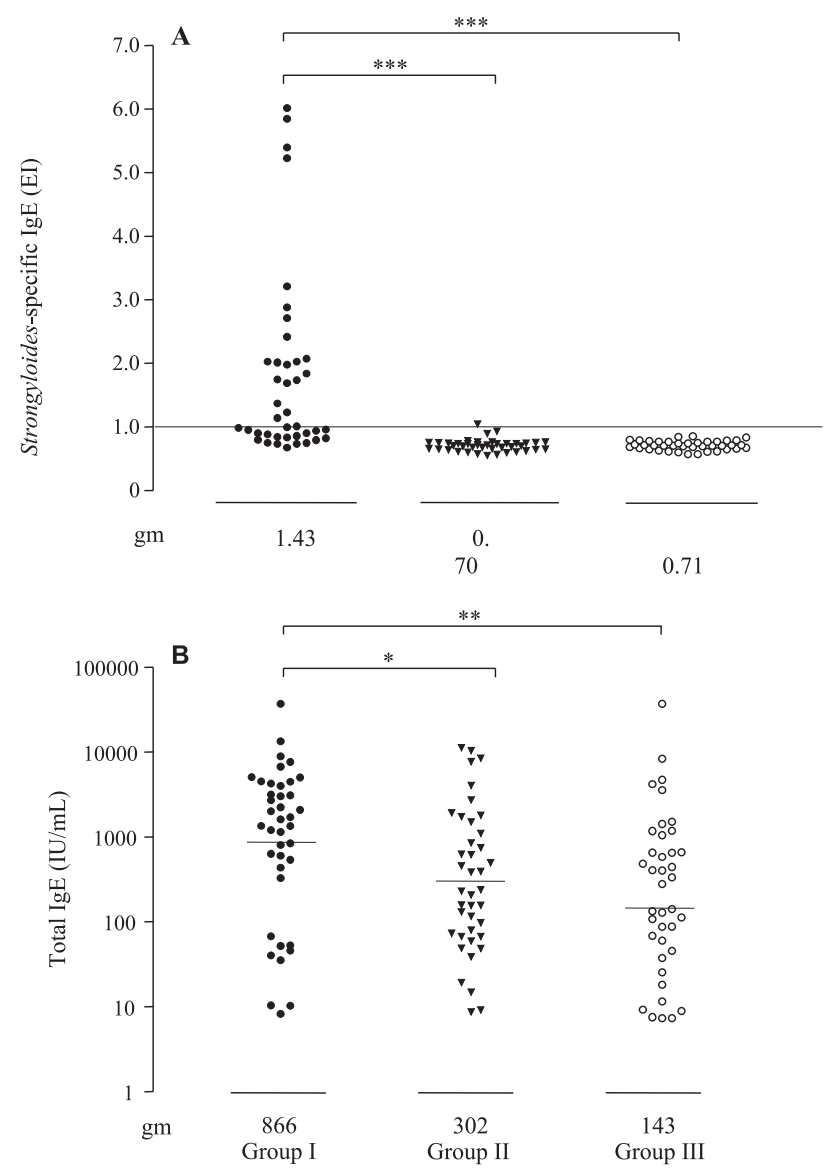

Fig. 1 - Levels of Strongyloides-specific IgE (A) expressed in ELISA Index (EI) and total IgE (B) expressed in IU/mL, determined by ELISA in serum samples from patients with strongyloidiasis (Group I; $n=40$ ), other intestinal parasites (Group II; $n=40$ ) and healthy subjects who had repeatedly negative stool examination (Group III; $n=40$ ). The dashed line in Fig. 1A represents the ELISA cut off (EI > 1.0). The horizontal bars in Fig. 1B indicate the geometric mean $(\mathrm{gm})$ of the total IgE levels (IU/mL) in each group. $* p<0.05$; * $p<0.01$; $* * * p<0.0001$.

For several years the detection of specific IgE to S. stercoralis had been performed by RAST using hazardous and radioactive material as well as expensive specific equipments ${ }^{13,20}$. The application of ELISA ${ }^{2,23}$ for the detection of human IgE anti-Strongyloides stercoralis, due to its high sensitivity and practicability, has helped the diagnosis by reducing costs and working under biosafety conditions.

The role of $\mathrm{IgE}$ antibodies has been implicated in acquired resistance to autoinfection in strongyloidiasis, resulting in a decrease in infection intensity and a consequent reduction in larval output. Therefore, IgEmediated responses may be essential in regulating autoinfection ${ }^{4}$.

The results of this study showed that the genus-specific serum IgE levels and positivity rate in the strongyloidiasis patients were significantly higher than those found in patients with other parasitic infections and healthy subjects. ATKINS et al. ${ }^{2}$ have demonstrated that levels of specific $\operatorname{IgE}$ to $S$. stercoralis were more elevated in serum from patients in recent than long standing chronic infection, suggesting that IgE levels are downregulated with increasing duration of infection.

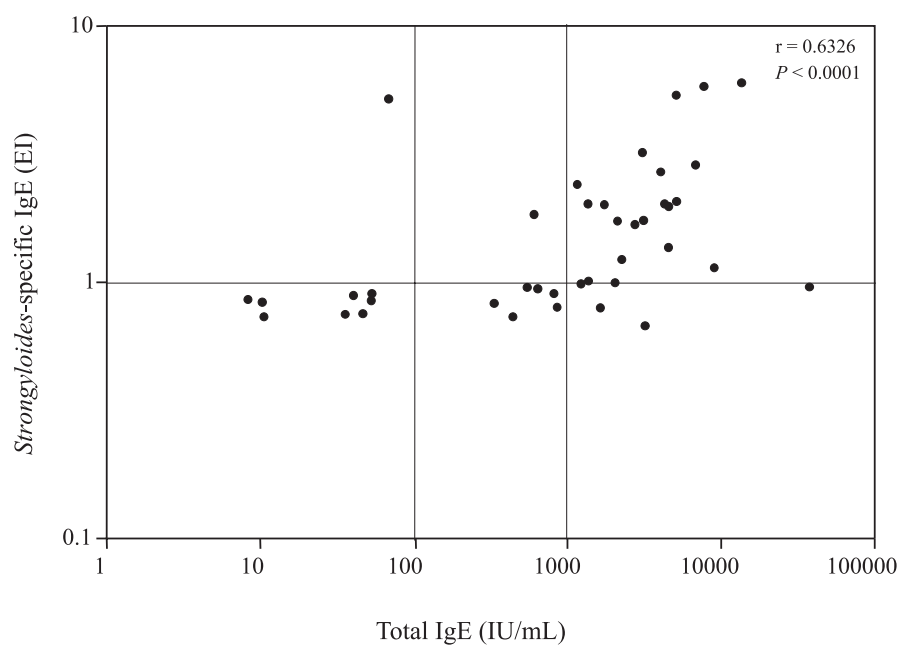

Fig. 2 - Correlation between levels of Strongyloides-specific IgE (EI) and total IgE (IU/mL) in serum samples from patients with strongyloidiasis (Group I; $n=40$ ), using Spearman correlation test. The dashed lines represent the cut off level of $1.0 \mathrm{EI}$ for genus-specific IgE and the arbitrarily considered values of 100 and $1000 \mathrm{IU} / \mathrm{mL}$ for total IgE levels.

According to NEVA et al. ${ }^{23}$, specific serum IgE levels are also much higher in patients infected with $S$. stercoralis as compared to co-infected patients with $S$. stercoralis and human T lymphotropic virus type I (HTLV-I). Thus, the HTLV-I infection associated to hyperinfection and disseminated strongyloidiasis is also related to supressed $\operatorname{IgE}$ antibody response $\mathrm{e}^{3,25}$.

In this study, the levels of total serum IgE were significantly higher in the group of patients with strongyloidiasis than in the other groups, as observed by others ${ }^{5,13,17}$. When comparing the levels of Strongyloidesspecific IgE and total IgE in sera from patients with strongyloidiasis a good and significant positive correlation was found, indicating that the high levels of total IgE seen in these patients were associated with the disease. In addition, the great majority of the patients with strongyloidiasis had a level higher than $1,000 \mathrm{IU} / \mathrm{mL}$ of total $\mathrm{IgE}$.

Taken together, it can be concluded that the employment of heterologous saline extract ( $S$. ratti) showed to be a useful tool for the detection of genus-specific IgE antibodies by ELISA, contributing for a better characterization of the immune response profile in human strongyloidiasis.

\section{RESUMO}

\section{Extrato antigênico heterólogo em ELISA para a detecção de IgE humana anti-Strongyloides stercoralis}

Extrato contendo larvas de Strongyloides ratti foi usado na padronização de um ELISA para detecção de IgE gênero-específica na estrongiloidíase humana. Foram analisadas 40 amostras de soro de pacientes monoinfectados que estavam eliminando larvas de $S$. stercoralis nas fezes (Grupo I), 40 de pacientes com outros parasitos intestinais (Grupo II), e 40 indivíduos copronegativos (Grupo III). Níveis de IgE gênero-específica (índice ELISA: EI) foram significativamente maiores no Grupo I $(E I=1,43)$ do que no II $(E I=0,70)$ e III $(E I=0,71)$, mostrando 
COSTA-CRUZ, J.M.; MADALENA, J.; SILVA, D.A.O.; SOPELETE, M.C.; CAMPOS, D.M.B. \& TAKETOMI, E.A. - Heterologous antigen extract in ELISA for the detection of human IgE anti-Strongyloides stercoralis. Rev. Inst. Med. trop. S. Paulo, 45(5):265-268, 2003.

positividade de $55 \%, 2,5 \%$ e $0 \%$, respectivamente. Similarmente, soros dos pacientes copropositivos (Grupo I) apresentaram níveis significativamente maiores de IgE total $(866 \mathrm{IU} / \mathrm{mL})$ quando comparados com os soros dos Grupo II (302 IU/mL) e III (143 IU/mL). Uma significativa correlação positiva foi encontrada entre os níveis de IgE específica a Strongyloides sp. e IgE total nos soros de pacientes com estrongiloidíase. Em conclusão, extrato heterólogo de $S$. ratti mostrou ser uma ferramenta útil para detecção de IgE gênero-específica por ELISA, desta forma contribuindo para melhor caracterização do perfil da resposta imune na estrongiloidíase humana.

\section{REFERENCES}

1. ADEDAYO, O.; GRELL, G. \& BELLOT, P. - Hyperinfective strongyloidiasis in the medical ward: review of 27 cases in 5 years. Sth. med. J. (Bgham, Ala.), 95: 711716,2002

2. ATKINS, N.S.; LINDO, J.F.; LEE, M.G. et al. - Humoral responses in human strongyloidiasis: correlations with infection chronicity. Trans. roy. Soc. trop. Med. Hyg., 91: 609-613, 1997.

3. ATKINS, N.S.; LINDO, J.F.; LEE, M.G. et al. - Immunomodulatory effects of concurrent HTLV-I infection in strongyloidiasis. J. AIDS hum. Retrov., 18: 188-190, 1998.

4. ATKINS, N.S.; CONWAY, D.J.; LINDO, J.F.; BAILEY, J.W. \& BUNDY, D.A.P. - L3 antigen-specific antibody isotype responses in human strongyloidiasis: correlation with larval output. Paras. Immunol., 21: 517-526, 1999.

5. BEZJAK, B. - Immunologlobulin studies in strongyloidiasis with special reference to raised serum IgE levels. Preliminary communication. Amer. J. trop. Med. Hyg., 24: 945-948, 1975

6. CONWAY. D.J.; ATKINS, N.S.; LILLYWHITE, J.E. et al. - Immunodiagnosis of Strongyloides stercoralis infection: a method for increasing the specificity of the indirect ELISA. Trans. roy. Soc. trop. Med. Hyg., 87: 173-176, 1993.

7. COSTA-CRUZ, J.M.; BULLAMAH, C.B.; GONÇALVES-PIRES, M.R.F.; CAMPOS, D.M.B. \& VIEIRA, M.A. - Cryo-microtome sections of coproculture larvae of Strongyloides stercoralis and Strongyloides ratti as antigen sources for the immunodiagnosis of human strongyloidiasis. Rev. Inst. Med. trop. S. Paulo, 39: 313-317, 1997.

8. COSTA-CRUZ, J.M.; MACHADO, E.R. \& CAMPOS, D.M.B. - Seroepidemiological study of human strongyloidiasis with blood samples collected on filter paper, in Abadia dos Dourados (Minas Gerais, Brazil). Rev. Inst. Med. trop. S. Paulo, 40: 329-331, 1998.

9. DREYER, G.; FERNANDES-SILVA, E.; ALVES, S. et al - Patterns of detection of Strongyloides stercoralis in stool specimens: implications for diagnosis and clinical trials. J. clin. Microbiol., 34: 2569-2571, 1996.

10. FERREIRA, M.S.; NISHIOKA, A.S.; BORGES, A.S. et al. - Strongyloidiasis and infection due to human immunodeficiency virus: 25 cases at a Brazilian teaching hospital, including seven cases of hyperinfection syndrome. Clin. infect. Dis., 28: 154-155, 1999.

11. FERRIOLI, F. - Condições que influem na extração de larvas do Strongyloides stercoralis das fezes pelo método de Looss-Baermann modificado (Técnica do pires). Rev. Inst. Med. trop. S. Paulo, 3: 51-60, 1961.

12. GAM, A.A.; NEVA, F.A. \& KROTOSKI, W.A. - Comparative sensitivity and specificity of ELISA and IHA for serodiagnosis of strongyloidiasis with larval antigens. Amer. J. trop. Med. Hyg., 37: 157-161, 1987.

13. GENTA, R.M.; DOULE, R.W. \& WALZER, P.D. - Diagnostic implications of parasitespecific immune responses in immunocompromised patients with strongyloidiasis. J. clin. Microbiol., 23: 1099-1103, 1986.
14. GROVE, D.I. \& BLAIR, A.J. - Diagnosis of human strongyloidiasis by immunofluorescence, using Strongyloides ratti and Strongyloides stercoralis larvae. Amer. J. trop. Med. Hyg., 30: 344-349, 1981.

15. HAGAN, P. - IgE and protective immunity to helminth infections. Paras. Immunol., 15: $1-4,1993$.

16. ISHIZAKA, T. - IgE and mechanisms of IgE-mediated hypersensitivity. Ann. Allergy, 48: 313-319, 1982

17. LEÃO, R.C.; BARROS, M.M.T. \& MENDES, E. - Immunological study of human strongyloidiasis. I. Analysis of IgE levels. Allergol. Immunopath., 8: 31-34, 1980.

18. LOWRY, O.H.; ROSEBROUGH, N.J.; FARR, A.L. \& RANDALL, R.J. - Protein measurement with the folin phenol reagent. J. biol. Chem., 29: 265-275, 1951.

19. LUTZ, A. - Schistosoma mansoni e a schistossomose, segundo observações feitas no Brasil. Mem. Inst. Oswaldo Cruz, 11: 121-125, 1919.

20. McRURY, J.; DE MESSIAS, I.T.; WALZER, P.D.; HUITGER, T. \& GENTA, R.M. Specific IgE responses in human strongyloidiasis. Clin. exp. Immunol., 65: 631638,1986

21. MINEO, J.R.; ROCHA, A.; COSTA-CRUZ, J.M. et al. - Total and specific antiTrypanosoma cruzi immunoglobulin E in pericardial fluid samples from patients with chronic Chagas disease. Trans. roy. Soc. trop. Med. Hyg., 90: 578-581, 1996.

22. MINISTÉRIO DA SAÚDE - Resolução $\mathbf{n}^{\circ}$ 196/96 sobre pesquisa envolvendo seres humanos. Brasília, Conselho Nacional de Saúde, 1996.

23. NEVA, F.A.; OLIVEIRA-FILHO, J.; GAM, A.A. et al. - Interferon- $\gamma$ and interleukin-4 responses in relation to serum IgE levels in persons infected with human $T$ lymphotropic virus type I and Strongyloides stercoralis. J. infect. Dis., 178: 18561859, 1998.

24. POLLART, S.M.; CHAPMAN, M.D.; FIOCCO, G.P.; ROSE, G. \& PLATTS-MILLS, T.A.E. - Epidemiology of acute asthma: IgE antibodies to common inhalant allergens as a risk factor for emergency room visits. J. Allergy clin. Immunol., 83: 875-882, 1989.

25. PORTO, M.A.F.; MUNIZ, A.; OLIVEIRA JÚNIOR, J. \& CARVALHO, E.M. Implicações clínicas e imunológicas da associação entre o HTLV-1 e a estrongiloidíase. Rev. Soc. bras. Med. trop., 35: 641-649, 2002.

26. ROSE, G.; ARLIAN, L.; BERSTEIN, D. et al. - Evaluation of household dust mite exposure and levels of specific $\operatorname{IgE}$ and $\mathrm{IgG}$ antibodies in asthmatic patients enrolled in a trial of immunotherapy. J. Allergy clin. Immunol., 97: 1071-1078, 1996.

27. SATO, Y.; KOBAYASHI, J. \& SHIROMA, Y. - Serodiagnosis of strongyloidiasis. The application and significance. Rev. Inst. Med. trop. S. Paulo, 37: 35-41, 1995.

28. SILVA, D.A.O.; GERVÁSIO, A.M.; SOPELETE, M.C. et al. - A sensitive reverse ELISA for the measurement of specific IgE to Der p 2, a major Dermatophagoides pteronyssinus allergen. Ann. Allergy Asthma Immunol., 86: 545-550, 2001.

29. SINGH, S. - Human strongyloidiasis in AIDS era: its zoonotic importance. J. Ass. Phycns. India, 50: 415-422, 2002.

30. SOUZA-ATTA, M.L.B.; ARAÚJO, M.I.; D’OLIVEIRA JÚNIOR, A.D. et al. - Detection of specific IgE antibodies in parasite diseases. Braz. J. med. biol. Res., 32: 1101$1105,1999$.

31. UPARANUKRAW, P.; PHONGSRI, S. \& MORAKOTE, N. - Fluctuations of larval excretion in Strongyloides stercoralis infection. Amer. J. trop. Med. Hyg., 60: $967-$ 973, 1999.

Received: 06 June 2003

Accepted: 26 September 2003 